\title{
Pasienter med \\ schizofreni bør få bedre diabetesoppfølging
}

Tidsmangel, mangel på kompetanse og ufaglært personell hindrer en god oppfølging og behandling av psykiatriske pasienters somatiske helse.

Schizofreni

Diabetes

Diabetessykepleier

\section{Hovedbudskap}

Artikkelen utforsker barrierene mot at også pasienter med schizofreni skal få en adekvat oppfølging av diabetes type 2. Jeg bruker mine egne erfaringer fra akuttpsykiatrien og relevant litteratur for å belyse hva (diabetes)sykepleiere kan gjøre for å forebygge diabetes og fremme mestring av sykdommen hos mennesker med schizofreni. 